\title{
Dissolved and particulate organic carbon and nitrogen in the Northwestern Mediterranean
}

\author{
M. D. Doval ${ }^{1 *}$, Fiz F. Pérez ${ }^{1}$ and Elisa Berdalet ${ }^{2}$ \\ ${ }^{1}$ Instituto de Investigaciones Marinas (CSIC). Eduardo Cabello 6, 36208 Vigo, Spain \\ ${ }^{2}$ Institut de Ciències del Mar (CSIC). P. Joan de Borbó s/n. 08039 Barcelona
}

*Corresponding author. Fax number: 34-86-292762. E-mail: marylo@iim.csic.es 


\begin{abstract}
The distribution of the concentrations of Dissolved Organic Carbon (DOC) and Nitrogen (DON) and Particulate Organic Carbon (POC) and Nitrogen (PON) was studied in a transect perpendicular to the Catalan coast in the NW Mediterranean in June 1995. The transect covered a hydrographically diverse zone, including coastal waters and two frontal structures (the Catalan and the Balear fronts). The cruise was conducted during the stratification period, characterized by the inorganic nutrient depletion in the photic zone and a well established deep chlorophyll $a$ maximum. DOC concentrations were measured using a high temperature catalytic oxidation method, and DON was determined directly, with an update of the Kjeldahl method after removal of inorganic nitrogen.

The ranges of DOC and DON concentrations were 44 to $95 \mu \mathrm{M}-\mathrm{C}$ and 2.8 to 6.2 $\mu \mathrm{M}-\mathrm{N}$, respectively. The particulate organic matter ranged between 0.9 and $14.9 \mu \mathrm{M}-\mathrm{C}$ and from 0.1 to $1.7 \mu \mathrm{M}-\mathrm{N}$. The DOC:DON molar ratios averaged $15.5 \pm 0.4$, while the mean POC:PON ratios was $8.6 \pm 0.6$. The distribution of dissolved organic matter (DOM) was inverse to that of the salinity. The highest concentrations of DOM were found in coastal waters and in the stations affected by the Catalan front, located at the continental shelf break.

It was estimated that recalcitrant DOM constituted the $67 \%$ of the DOM pool in the upper $50 \mathrm{~m}$. The data suggest that accumulation of DOC due to the uncoupling between the production and consumption mechanisms may occur in the NW Mediterranean during the stratification period and that the organic matter exported from the photic layer is dominated by C-rich bioelements.
\end{abstract}




\section{INTRODUCTION}

Dissolved organic matter (DOM) had been traditionally ignored, in part, due to methodological constraints and also because it was considered biologically inert (Barber, 1968; Williams and Druffel, 1987). Relatively recent data indicate that dissolved organic carbon (DOC) represents quantitatively the most important carbon reservoir in the ocean (Walsh, 1989; Wangersky, 1993; Cauwet, 1994; Bronk et al., 1994; Lefèvre et al., 1996). Thus, DOC may play a major role in the carbon cycle in the planet (Toggweiler, 1989; Copin-Montégut and Avril, 1993; Carlson and Ducklow, 1995; Ducklow et al., 1995), a role mostly attributed to the particulate organic carbon (POC). In addition, dissolved organic nitrogen (DON) appears to be the dominant form of fixed nitrogen in oligotrophic surface waters (Jackson and Williams, 1985; Walsh, 1989). There is no longer doubt that both DOC and DON should be included in biochemical models (Bronk et al., 1994; Kirchman et al., 1994). Nevertheless, very few information is available about the characterization, transformation or even the absolute concentration of DOM in seawater (Sharp et al., 1993a; 1993b).

The oligotrophic waters of the Mediterranean Sea constitute an example of these not well understood areas with regards to the DOM concentration. In the Western Basin, DOC data are only available from the Gulf of Lions and the Ligurian Sea (Cauwet et al., 1990; Copin-Montégut and Avril, 1993; Cauwet, 1994) and estimations of DON concentrations have only been performed in the Alboran Sea (Coste et al., 1988) and the East of Sardinian coast and in the SE Cabo de Palos (Banoub and Williams, 1972). Compared to the rest of the Mediterranean Sea, the areas of the Western Basin are characterized by a relatively increased productivity. The mesoscale hydrographic structures, namely, the Alboran gyres and the mixing chimneys in the 
Gulf of Lions, facilitate nutrient inputs to the photic zone (San Feliu and Muñoz, 1971; Minas et al., 1984; Taupier-Lepage and Millot, 1988). The values of DOC in this area were similar to those reported in other oligotrophic areas such as the equatorial Pacific (Carlson and Ducklow, 1995) or equatorial Atlantic (Thomas et al., 1995).

In the Catalano-Balear Sea, located between the Northeastern Spanish coast and the Balearic Islands, the shelf-slope fronts along the continental and insular coasts and the breaking of internal waves at the thermocline play also an important fertilizing role (Estrada and Margalef, 1988). These hydrographic mechanisms and their variability appear to contribute to the maintenance of an otherwise low biomass, specially during the stratification period which extends from April to November (Estrada, 1985). Inorganic nutrients inputs may occur at the level of the thermocline, but both nitrogen and phosphorus are close to the detection limit in the photic zone. It can not be discarded that organic forms may support part of the primary and heterotrophic production in summer. In the vertical dimension, during the stratified period, a well developed deep chlorophyll a maximum (DCM) is present. This formation is due to photoacclimation of cells to low light levels and the availability of nutrients in waters close to the surface (Estrada et al., 1993). For instance, it was estimated that in summer 1983, the phytoplankton of the DCM contributed up to $30 \%$ of the total primary production in the water column (Estrada, 1985). Thus, it may be likely that relatively important DOC concentrations occur in this area. Unfortunately, data on DOC and DON concentrations are not available.

In June 1995, during the summer stratification period, a cruise was conducted in the Catalan Sea. The study included a transect perpendicular to the coast of Barcelona, which covered a hydrographically diverse area, from the continental shelf to the open 
sea waters. Samples for the simultaneous determination of DOC and DON and, POC and PON concentrations were collected. A main objective was to study the spatial variability in the distribution of both the dissolved and the particulate organic matter related to the hydrography. In addition, we investigated the relationship among the four chemical measurements which will contribute to understand the dynamics of carbon and nitrogen in the NW Mediterranean.

\section{MATERIAL AND METHODS}

\section{Sample collection}

Samples were collected in June 6, 1995 on board the B/O Hesperides during the "VARIMED`95" cruise (that extended from the 2nd to the 14th of June). Sampling was conducted along a transect between Barcelona and the Mallorca-Menorca channel (Fig. 1). Starting at station $\# 1$, nine stations were sampled between $41^{\circ} 20^{\prime} \mathrm{N} 2^{\circ} 17^{\prime} \mathrm{E}$ and $40^{\circ} 27^{\prime} \mathrm{N} 3^{\circ} 2^{\prime}$ E from 5:00 to 10:30 GMT. At each station, temperature, salinity, oxygen and pressure were recorded by means of a CTD (Neil Brown Mark III) probe. Water samples were obtained with a Rosette sampler (12 l Niskin bottles) attached to the CTD system. Discrete samples of $\mathrm{O}_{2}$ were collected and analyzed by Winkler potentiometric titration (Culberson, 1981) to calibrate the $\mathrm{O}_{2}$ sensor of the CTD probe.

Water samples were taken at 5, 30, 50, 100, 200, 500, $1000 \mathrm{~m}$ depth and at bottom for DOC, POC and PON concentrations and, at 5, 50, 100, 200, $1000 \mathrm{~m}$ depth and at bottom for DON concentrations. For chlorophyll $a$ concentrations samples were collected at $10 \mathrm{~m}$ intervals between surface and $100 \mathrm{~m}$, and at $150 \mathrm{~m}$ and at $200 \mathrm{~m}$ depth. 
The bottles and the filtering system used for the organic matter analyses had been previously soaked on diluted sodium hypochloride, $0.1 \mathrm{~N}$ hydrochloric acid and rinsed with Milli-Q water. Samples were drawn into clean $1 \mathrm{~L}$ polyethylene containers. Just before filling, the containers were rinsed three times with the water sample. A completely glass filtering system was used to collect the particulate and the dissolved organic matter. Filtration onto Whatman GF/F filters was performed immediately after sampling.

Particulate organic matter and Chlorophyll a determinations

Particulate organic carbon (POC) and nitrogen (PON) were collected on Whatman GF/F filters, which were dried on silica gel and frozen to $-70^{\circ} \mathrm{C}$ until analysis in the laboratory. Measurements were carried out with a 'Perkin Elmer 2400 CHN' analyzer. Prior to the analyses, carbonates were eliminated from the samples with hydrochloric acid vapour. Combustion to $\mathrm{CO}_{2}$ and $\mathrm{NO}_{\mathrm{x}}$ was performed at $900^{\circ} \mathrm{C}$ and reduction of $\mathrm{NO}_{\mathrm{x}}$ to $\mathrm{N}_{2}$ at $640^{\circ} \mathrm{C}$. The reproducibility of the method was $\pm 0.1 \mu \mathrm{M}$ for POC and $\pm 0.04 \mu \mathrm{M}$ for PON. Aliquots of the filtrate were taken for DOC and DON analyses. The initial filtrate was used to rinse the bottles before filling them with the water sample. For DON and DOC analyses, samples were immediately frozen $\left(-70^{\circ} \mathrm{C}\right)$ until analyses.

Chlorophyll a concentration was estimated fluorometrically (Strickland and Parsons, 1968). Samples (100 ml) were collected in 25 mm GF/F glass fibber filters and immediately frozen at $-70^{\circ} \mathrm{C}$. The filters were then left for $12 \mathrm{~h}$ in $90 \%$ acetone at $4^{\circ} \mathrm{C}$ in the dark for pigment extraction. The fluorescence of the extract was measured in a 
Turner Designs fluorometer calibrated with natural samples collected in the same cruise and measured spectrophotometrically (Jeffrey and Humphrey, 1975).

\section{DOC measurements}

DOC analyses were performed (within 2 days) with a commercially available automatic analyzer Shimadzu TOC-5000. This apparatus operates on the principle of high temperature catalytic oxidation (HTCO) of organic compounds in liquid samples. Samples were acidified with $0.5 \mathrm{ml}$ of $2.5 \mathrm{~N} \mathrm{HCl}$ to $\mathrm{pH} 2$. Intense bubbling of pure synthetic air throughout the sample for $10 \mathrm{~min}$. allowed complete decarbonation. Thus, the measured DOC was not purgable organic carbon. Some volatile organic carbon (VOC) may be lost at room temperature by acidification and purging. Nevertheless, the contribution of the VOC to the DOC value (less than 1\%) is considered insignificant (Wangersky, 1993). The decarbonated sample was pumped by a glass syringe and injected into a vertical furnace (combustion quartz tube) which was filled with a $0.5 \%$ Pt on $\mathrm{Al}_{2} \mathrm{O}_{3}$ catalyst. Three to 5 replicate injections of $200 \mu \mathrm{l}$ were performed per sample. The concentration of DOC was determined by subtracting system blank area from the average peak area and dividing by the slope of the standard curve (Thomas et al., 1995). The system blank is the instrument blank plus DOC in UV-Milli-Q water plus the filtration blank. Measurements made with the high sensitivity catalyst (platinum on silica wool) produced values $<2 \mu \mathrm{M}-\mathrm{C}$ for fresh UV-Milli-Q water. The filtration blank (determined by filtering UV-Milli-Q water through the filtration system) was $\sim 5 \mu \mathrm{M}-\mathrm{C}$. Before sample analyses, the catalyst was washed by injecting UV-Milli-Q, for at least $12 \mathrm{~h}$, until the instrument blank was low and stable. The instrument blank was $<8 \mu \mathrm{M}-\mathrm{C}$; when it was higher, we washed or even replaced the 
catalyst. The system was standardized with Potassium Hydrogen Phthalate (KHP). A two-points calibration ( 0 and $200 \mu \mathrm{M} \mathrm{C}$ ) was performed routinely every 20 samples with freshly prepared running standards. The coefficient of variation (C.V.) of the peak area for the 3-5 replicates of each sample was $\sim 1 \%$.

\section{DON measurements}

Most procedures for the determination of the DON are based on the estimation of the total dissolved nitrogen (TDN) from which it is subtracted the independently measured inorganic nitrogen concentration (DIN: nitrate, nitrite and ammonium). Thus, the estimation of DON by this method, accounts for the inaccuracies introduced by the TON and the DIN quantification. In the present study, DON was directly measured by an updated Kjeldahl method (Doval et al., 1997a). A volume of $100 \mathrm{ml}$ of sample was introduced into a $300 \mathrm{ml}$ Pyrex Kjeldahl flask. To eliminate ammonium, $1 \mathrm{ml}$ of $0.5 \mathrm{~N}$ $\mathrm{NaOH}$ was added and the solution was boiled until the sample volume was reduced by a half. Next, $10 \mathrm{ml}$ of $\mathrm{H}_{2} \mathrm{SO}_{4}-\mathrm{FeSO}_{4}$ reagent were added to concentrate the sample and remove nitrogen oxides. The heating must go on to convert DON to ammonium in acid medium. The residue was diluted with UV-Milli-Q water and carried to a distillation device, where $20 \mathrm{ml}$ of $33 \% \mathrm{NaOH}$ were added and the resulting ammonia was codistilled with water vapour until $20 \mathrm{ml}$ were collected over $5 \mathrm{ml}$ of $10^{-3} \mathrm{M} \mathrm{HCl}$. Ammonium concentration on the distillate, directly related to DON in the sample, was finally determined with the SFA system. The average blank was $2 \mu \mathrm{M}-\mathrm{N}$ and it was subtracted from DON values. We analysed duplicate seawater samples, being the C.V. $5 \%$. 


\section{RESULTS}

\section{Hydrographic conditions}

The studied transect covered three main water masses, identified by the salinity distribution, from West to East: coastal water, Local Mediterranean Water and Modified Atlantic Water (Fig. 2A). The Catalan Front was located at the continental slope, around station \#3. This continental front separated low salinity $(<38.0)$ shelf water from the more saline offshore one. The Local Mediterranean Water, extended from stations \#4 to \#7. At the easternmost part of the transect, the presence of the Balear Front was noticed between stations \#7 and \#8 at surface. This shallower front separated the Local Mediterranean Water from recent Modified Atlantic Water that has entered the Balearic Basin through the Ibiza channel (Salat and Cruzado, 1981).

All water masses were thermally stratified (Fig. 2B). A marked thermocline extended from approximately 10 to $60 \mathrm{~m}$ depth along the transect. Associated to the thermocline, deep chlorophyll $a$ maxima (DCM) were found (Fig. 2C). At the depth of the DCM (between 30 and $60 \mathrm{~m}$ ) chlorophyll $a$ concentrations reached $1.4 \mathrm{mg} \mathrm{m}^{-3}$. Close to the coast, chlorophyll $a$ concentrations were lower than offshore and the DCM was weak. Within the transect, the highest chlorophyll $a$ concentrations were associated to the frontal structures.

Oxygen distribution presented concentration maxima between 30 and $50 \mathrm{~m}$, i.e. at the basis of the thermocline (Fig. 2D). Oxygen concentrations were higher at the central zone than at the two extremes of the transect.

\section{Particulate and dissolved organic matter distributions}


The distribution of the PON and POC (Figs. 3A and 3B) showed maximum values at the level of the DCM. At this level, stations \#3 and \#6 presented the highest values of POC (14 and $8 \mu \mathrm{M}$, respectively) and PON (1.8 and $1.4 \mu \mathrm{M}$, respectively).

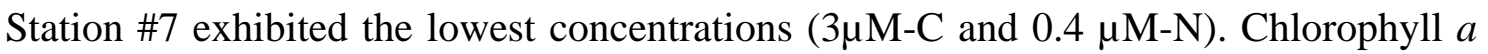
and POM concentrations were not related; considering all data pairs, the determination coefficient of the linear regression (Model II, Sockal and Rolhf, 1995) was low and not significant $\left(r^{2}<0.30\right)$. The distribution of the C:N molar ratio of the POM (POC:PON, Fig. 3C) increased specially eastwards. In general, the distribution of the POC:PON ratio showed minimum values (ca. 6) at the depth of the DCM. On average the POC:PON molar ratios were $8.6 \pm 0.6$ ( $n=63$, Table 1). POC and PON showed parallel trends, as indicated by the high and significant determination coefficient found, when considering the whole data set (Table 1).

The average concentrations and variation ranges of DOC and DON in the upper $100 \mathrm{~m}$ and between $200 \mathrm{~m}$ to $2000 \mathrm{~m}$ are summarized in Table 2 and 3 . In addition, DOC and DON reported by other authors are compared. In general, vertical profiles of DOC and DON presented maximum values at surface, in the photic zone, and decreased with depth (Fig.4A and 4B). At 50 m depth, coinciding with the DCM and the oxygen maxima, slightly minimum concentrations of DON and, specially of DOC, were observed (stn. \#2, \#3, \#4, \#7 and \#9). Below $500 \mathrm{~m}$ the low concentrations were nearly homogeneous. In station \#1, where the water column was mixed, DOC and DON were fairly uniformly distributed. An example of the vertical profiles of DOC and DON concentration compared to that of temperature is illustrated for station \#7, which also constituted the deepest sampled station (Fig. 5). 
The distribution of the DOM (Figs. 4A and 4B) appeared to be inverse to that of the salinity (Fig. 2A). The coastal and Catalan front stations, characterized by low salinity values, presented the highest DON and DOC concentrations. Opposite trends were observed at the central stations. It was worth noting the similarity of the 38.2-38.3 isolines and the $60 \mu \mathrm{M}-\mathrm{C}$ and $4 \mu \mathrm{M}-\mathrm{N}$ isolines, with the characteristic doming at the central stations. Considering the whole data set, DOC and salinity (S) were significantly related following the expression:

$$
\begin{gathered}
\text { DOC }( \pm 7.8)=1669( \pm 151)-42( \pm 4) S \\
r^{2}=0.65 \quad n=63 \quad p<0.001
\end{gathered}
$$

The lineal regression between DON and S was slightly lower $\left(r^{2}=0.57\right)$. These regressions increased when the surface values of stations \#8 and \#9 (with minimum S and different water masses) were not included $\left(\mathrm{r}^{2}=0.74, \mathrm{p}<0.001\right)$.

In general, the distribution pattern of the DON and DOC concentrations was very similar and the lineal regression between the two parameters was significant $\left(r^{2}=0.83\right.$, Table 1$)$. The distribution of the C:N molar ratio of DOM (DOC:DON) increased slightly with depth and eastwards (Fig. 4C). The lowest C:N molar ratios were found in surface waters of the coastal stations (ca. 13). DOC:DON ratios oscillated between 13 and 19, with a mean value of $15.5 \pm 0.4(n=47$, Table 1$)$. Significant relations were found between DOC and POC and between DON and PON $\left(r^{2}=0.50\right.$, Table 1$)$. However, DOM and chlorophyll $a$ were not significantly related.

\section{DISCUSSION}


The hydrographic conditions found during the VARIMED`95 cruise were typical of the stratification season in the open sea waters of the study area (Pérez et al., 1986; Font et al., 1988). During this stratification period, the presence of the Catalan and the Balear fronts appear to play an important role in the fertilization of this area (Estrada and Margalef, 1988; Estrada and Salat, 1989). The doming of the isolines between the two frontal systems is a consistent trend registered in other cruises (Estrada and Margalef, 1988; Estrada and Salat, 1989; Estrada et al., 1993). It is considered that this hydrographic feature helps also to maintain relatively important biomass levels by rising the nutrient rich waters to the surface. This can be evidenced by the increase in the chlorophyll $a$ and in the POC and PON concentrations as well, near the frontal structures and at the basis of the thermocline (Figs. 2C and 3A, 3B). The particular distribution of the oxygen maxima, slightly shallower than the DCM agrees with the pattern of vertical distribution of primary production maxima reported in this area (Estrada et al., 1993). In addition, the slightly minimum of DOC concentrations (stn. \#2, \#3, \#4, \#7 and \#9) agrees with the maximum of biological activity at the DCM.

Nevertheless, the total microplanktonic biomass, estimated from the POC and PON values, did not match chlorophyll $a$ concentration distribution. This is due, partly from the different contribution of the phytoplanktonic versus the total plankton community (Alcaraz et al., 1985), and the degree of coupling between the autotrophic biomass and the rest of the planktonic organisms in the different zones of the studied transect (Vaqué et al., 1994; Calbet et al., 1996).

The relevant role of the hydrographic conditions in the biogeochemical processes was also noted in the distribution of the DOM. The significant relationship between DOM and salinity suggests that physical processes highly controlled the 
mesoscale distribution of DOM in the water column in the studied area. Furthermore, the inverse relationship indicates that, coastal waters, near Catalan front, were a important source of DOM. In the studied area, the river water discharges come from the Arno to Ebro with a maximum river runoff in the inner shelf of the Gulf of Lions, corresponding to the Rhòne (Salat 1996 and references there in). Therefore, the low salinity waters must have traveled a long way and they had been mixed with high salinity waters. In the open ocean, only about $10 \%$ of the DOC is estimated to be of terrestrial origin (Meyers-Schulte and Hedges, 1986). Thus, the higher concentrations of DOC in surface waters compared to deeper layers are likely the result of the biological activity since the stabilization of the water column. The small scale and biological variability affecting the production and consumption processes of DOC and DON will be reported elsewhere (Berdalet et al., in prep.; Gasol et al., 1998).

This work constitutes a first data set obtained in the Mediterranean Sea with simultaneous determination of DOM and POM. POC and PON concentrations were in the same range as those obtained by other authors in Mediterranean waters (Banoub and Williams, 1972; Copin-Montégut and Copin-Montégut, 1983; Alcaraz et al., 1985).

The DOC values measured in our cruise were in the range reported by other studies in the Western Basin of the Mediterranean Sea (Table 2). With the exception of the data provided by Banoub and Williams (1972) using the peroxidisulfate oxide method, all the available data were obtained by the HTCO technique. The data obtained in our cruise in the open sea waters, fall also in the same range recently reported for other oligotrophic areas (range: 35-110 M-C; Tupas et al., 1994; Thomas et al., 1995; Sharp et al., 1995; Carlson and Ducklow, 1995 and Chen et al., 1996). The range of 
DOC values were lower than that obtained from a richer ecosystem, the Ria de Vigo (NW Spain), with average chlorophyll $a$ of $6.2 \mu g \mathrm{I}^{-1}$ (average DOC: $107 \mu \mathrm{M}-\mathrm{C}$ ) in the surface layer and $1.1 \mu \mathrm{g} \mathrm{l}^{-1}$ (average DOC: $77 \mu \mathrm{M}-\mathrm{C}$ ) in the bottom layer (45 m deep), during summer (Doval et al., 1997b).

The DON concentrations obtained in the VARIMED'95 cruise were close to those estimated using the UV-oxidation method $\left(\mathrm{DON}+\mathrm{NH}_{4}{ }^{+}\right)$by Banoub and Williams (1972) in the western Mediterranean waters and by Coste et al. (1988) in the Alboran Sea (Table 3). Using the Kjeldahl modified method, Fraga $(1966,1969)$ measured the same range of DON for Indian waters (2.0-8.0). Finally, similar values were found by Doval et al. (1997a) in the eastern North Atlantic (3.0-11.0).

In the present study, DOC and DON constituted approximately the $90 \%$ of the total organic carbon $(\mathrm{POC}+\mathrm{DOC})$ and nitrogen $(\mathrm{PON}+\mathrm{DON})$ in the whole water column. The percentage of DOC was similar to that estimated by Cauwet et al. (1990) in Mediterranean waters. This finding corroborates the important role of DOC as a major form of carbon export in the Mediterranean Sea as first suggested by CopinMontégut and Avril (1993).

During the stratification period inorganic nutrients are, in general, close to the detection limit in the photic zone (Minas et al., 1988) and this was the case during the VARIMED'95 cruise (Berdalet et al., 1996a; Berdalet et al., in prep). Nevertheless, the $\mathrm{C}: \mathrm{N}$ molar ratio of the POM, close to 7 in most part of the transect, would agree with the idea that the microplankton communities were not nitrogen limited (Berdalet et al., in prep.), at least during the studied season. Similar high C:N ratios of DOM have been reported by other authors in different areas (Jackson and Williams 1985; Hansell et al, 1993; Williams, 1995; Chen et al, 1996; Doval et al, 1997b), and mechanisms other 
than preferential DON over DOC consumption have also been proposed to explain the accumulation of C-rich DOM (Williams, 1995).

A main issue with regards to the dissolved organic matter is its availability to the microorganisms. The bulk DOC pool can be separated into the highly labile, the semi-labile and the refractory pools (Kirchman et al,. 1993). Following Carlson and Ducklow (1995), the labile pool consists on biologically available organic matter that turns over on time scales of hours to days; the semi-labile pool turns over on a seasonal time scale; and the refractory DOC, representative of deep waters has an average life time of 6000 years (Williams and Druffel, 1987). In surface waters, all pools are present. The concentration of "new" (i.e. non-refractory) DOC depends highly on the balance between its in situ production by different biological processes and its consumption within the food web as well.

DOM partitioning has been estimated with a simple 1-D model as used by Carlson and Ducklow (1995) and Cherrier et al. (1996) in oligotrophic gyres. In our study, the average DOC was $78 \pm 7 \mu \mathrm{M}$ at the surface waters, $72 \pm 10 \mu \mathrm{M}$ for waters in the upper $50 \mathrm{~m}, 62 \pm 9 \mu \mathrm{M}$ at $100 \mathrm{~m}$ and $49 \pm 3 \mu \mathrm{M}$ for waters below $500 \mathrm{~m}$. Assuming that the recalcitrant material is homogeneously distributed in the water column (Carlson and Ducklow, 1995), and the DOC pool at depth $>500 \mathrm{~m}$ is essentially refractory, $49 \pm 3 \mu \mathrm{M}$ would correspond to the recalcitrant DOC concentration. It would constitute the $68 \%$ of the total DOC in the upper $50 \mathrm{~m}$ or the $63 \%$ of surface DOC; i.e. the nonrefractory DOC or DOC excess (semi-labile + labile) was the $37 \%$ of the surface DOC. We could assume the presence of two main fractions of DOC at $100 \mathrm{~m}$ depth (refractory and semi-labile), as found by Cherrier et al. (1996) below the DCM in the North Pacific. The semi-labile pool would then account for $c a .13 \mu \mathrm{M}-\mathrm{C}$, which corresponds 
to the $17 \%$ of surface DOC. Finally, the remaining $16 \mu \mathrm{M}-\mathrm{C}$ obtained from the difference between average surface DOC and the other two fractions were about the $20 \%$ of the surface DOC. But, we only can only calculate two fractions of DOM: excess (semi-labile + labile) and refractory with our data base. It can be considered that DOC excess has been accumulated in surface water since winter mixing.

Similar calculations can be performed for the estimation of the recalcitrant, semi-labile and labile DON pools. The average DON was $5.2 \pm 0.5 \mu \mathrm{M}$ at the surface waters, $4.8 \pm 0.8 \mu \mathrm{M}$ in the upper $50 \mathrm{~m}, 3.9 \pm 0.5 \mu \mathrm{M}$ at $100 \mathrm{~m}$ and $3.1 \pm 0.3$ below 500 m. The concentrations obtained were: 3.1, 0.8 and $1.2 \mu \mathrm{M}-\mathrm{N}$ for the recalcitrant, semilabile and labile DON pools, respectively. These concentrations correspond to the $60 \%$, $16 \%$ and $24 \%$ of the surface DON, respectively. DON excess constitute the $30 \%$ of surface DON. The C:N molar ratio of DOM was higher in the refractory pool ( 16) than in the more labile fraction $(\sim 13)$, as expected. It is noted that the $\mathrm{C}: \mathrm{N}$ molar ratio of the fraction more labile (semi-labile+labile) is similar to the slope of the direct lineal regression between DOC and DON (13.3; Table 1).

The percentage of the recalcitrant DOC (63\% of surface DOC or $68 \%$ of the upper $50 \mathrm{~m} \mathrm{DOC)}$ was similar to that estimated by others authors in oligotrophic areas (Carlson and Ducklow, 1995; Thomas et al., 1995 and Chen et al. 1996). A wider range of refractory DOC (50-100\%) was found by Copin-Montégut and Avril (1993) in the Northwestern Mediterranean during the annual cycle studied. The amount of semilabile DOC (about $11 \mu \mathrm{M}-\mathrm{C}$ ) estimated in the surface waters was similar to the seasonal variability observed in surface waters of the Ligurian Sea by Copin-Montégut and Avril (1993). It has been suggested that grazing pressure on bacteria or nutrient limitation would result in low bacterial activity and thus, DOC accumulation in surface waters 
(Williams, 1995; Thingstad and Rassoulzadegan, 1995; Chen et al., 1996). The VARIMED'95 cruise was conducted in June, i.e. approximately after three months since the beginning of the stabilization of the water column with the subsequent development of phytoplankton and microbial biomass. Low concentration of labile DOC would have been expected if the production and consumption mechanisms were tightly coupled as it seems to occur in the Equatorial Pacific (Carlson and Ducklow, 1995). Nevertheless, this could not be the case for the NW Mediterranean where phosphorus seems to play a main limiting role (Berland et al., 1980; Thingstad and Rassoulzadegan, 1995; Berdalet et al., 1996b). Detailed studies on bacterial production and respiration yields should allow to properly quantify the highly-labile DOC (Norrman et al., 1995; Giorgio et al., 1997).

The present study was addressed to contribute to the understanding of the carbon cycle in the NW Mediterranean. Nevertheless, many opened questions remain. Further seasonal studies on the temporal and spatial DOM variability should be conduced to know the different magnitude of the biological and physical control of the origin and fate of the organic matter in this area.

Acknowledgments. The authors thank the participants in the cruise VARIMED'95 and the crew of the R/V Hesperides for their valuable help. We specially acknowledge Dr. C. Marrasé for providing chlorophyll $a$ concentrations data, Dr. F. Peters for conducting oxygen calibrations and Dr. T. Granata for the physical data. We also thank M. V. González and J. M. Anguita for their help in the preparation of the figures. A fellowship from the EC MAST2 project CT93-0065 allowed M. D. Doval to carry out this work. The projects from 
Medipelagos: MAS2-CT93-0065 and from CICYT: AMB94-0853 and AMB94-1019 financed in part this work. We thank Dr. X. A. Álvarez-Salgado for their valuable comments. 


\section{REFERENCES}

Alcaraz, M., Estrada, M., Flos, J. and Fraga, F. 1985 Particulate carbon and nitrogen and plankton biomass in oligotrophic and upwelling systems. International Symposium Upwelling Western Africa, Instituto Investigacion Pesquera, Barcelona, I, 435-448

Banoub, M. W. and Wiliams, P .J. le B. (1972) Measurements of microbial activity and organic material in the western Mediterranean Sea. Deep-Sea Research, 19, 433-443

Barber, R. T. (1968) Dissolved organic carbon from deep waters resist microbial oxidation. Nature, 220, 274-275

Berdalet, E., Arin, L., Marrasé, C., Cruzado, A. and Estrada, M. (1996a) Limiting nutrients and biochemical composition of natural microbial communities in the NW Mediterranean. 2nd Workshop of the Mediterranean Targeted Project. Crete, 1996

Berdalet E., Arin, L., Fara, A., Marrasé, C. and Estrada, M.(1996b) Phosphorus limitation in the NW Mediterranean. 5th European Marine Microbiology Symposium, Bergen, Norway, 1996

Berland, B. R., Bonin, D. J. Maestrini, S. Y. (1980) Azote ou phosphore? Considérations sur le "paradoxe nutritionnel" de la mer méditerranée. Oceanologica Acta, 3: 135-142

Bronk, D. A., Glibert, P. M. and Ward, B. B. (1994) Nitrogen uptake, dissolved organic nitrogen release, and new production. Science, 265, 1843-1846

Calbet, A., Alcaraz, M., Saiz, E., Estrada, M. and Trepat, I. (1996) Planktonic herbivorous food webs in the Catalan Sea (NW Mediterranean): temporal variability and comparison of indices of phyto-zooplankton coupling based on state variables and rate processes. Journal of Plankton Research, 18, 2329-2347 
Carlson, C. A. and Ducklow, H. W. (1995) Dissolved organic carbon in the upper ocean of the central equatorial Pacific Ocean, 1992; Daily and finescale vertical variations. Deep-Sea Research II, 42, 639-656

Cauwet, G., Sempere, R. and Saliot, A. (1990) Carbone organique dissous dans l'eau de mer: cofirmation de la sous-estimation antérieure. C.R. Acad. Sci. Paris, t.311, Série II, 1061-1066

Cauwet, G. (1994) HTCO method for dissolved organic carbon analysis in seawater: influence of catalyst on blank estimation. Marine Chemistry 47, 55-64

Coste, B., Le Corre, P. and Minas, H. J. (1988) Re-evaluation of the nutrient exchange in the Strait of Gibraltar. Deep-Sea Research, 35, 767-775

Copin-Montégut, C. and Copin-Montégut, G. (1983) Stoichiometry of carbon, nitrogen, and phosphorus in marine particulate matter. Deep-Sea Research, 30, 31-46

Copin-Montégut, G. and Avril, B. (1993) Vertical distribution and temporal variation of dissolved organic carbon in the North-Western Mediterranean Sea. Deep-Sea Research I, 40, 1963-1972

Chen, R. F., Fry, B., Hopkinson, C. S., Repeta, D. J., Peltzer, E. T. (1996) Dissolved organic carbon on Georges Bank. Continental Shelf Research, 16, 409-420

Cherrier, J., Bauer, J. E., Druffel, E. R. M. (1996) Utilization and turnover of labile dissolved organic matter by bacterial heterotrophs in eastern North Pacific surface waters. Marine Ecology Progress Series, 139, 267-279

Culberson, C. H. (1981) Direct potentiometry in marine electrochemistry. In: Marine Electrochemistry. Whitfield and Jagner. (editors): J.Wiley and Sons, Ltd. 522 pp. 
Doval, M. D., Fraga, F., Pérez, F. F. (1997a) Determination of dissolved organic nitrogen in seawater using Kjeldahl digestion after inorganic nitrogen removal. Oceanologica Acta, 20, 713-720

Doval M. D., Álvarez-Salgado, X. A., Pérez, F. F., (1997b) Dissolved organic matter in a temperate embayment affected by coastal upwelling. Marine Ecology Progress Series, 157, 21-37

Ducklow, H. W., Carlson, C. A. , Bates, N. R., Knap, A. H. and Michaels, A. F. (1995) Dissolved organic carbon as a component of the biological pump in the North Atlantic Ocean. Phil. Trans. R. Soc. Lond. B. 348, 161-167.

Estrada, M. (1985) Deep phytoplankton and chlorophyll maxima in the Western Mediterranean. In: Marine Mediterranean Ecosystems, ed. MoraitouApostopoulou, M. Kiortsis, V, pp. 247-277. Plenum Press. New York and London

Estrada, M. and Margalef, R. (1988) Supply of nutrients to the Mediterranean photic zone along a persistent front. Oceanologica Acta Special Issue, 9, 133-142

Estrada, M. and Salat, J. (1989) Phytoplankton assemblages of deep and surface waters layers in a Mediterranean frontal zone. Topics in Marine Biology, ed. J. D. Ros Scientia Marina, 53, 203-214

Estrada, M., Marrasé, C., Latasa, M., Berdalet, E., Delgado, M. and Riera, T. (1993) Variability of deep chlorophyll maximum characteristics in the Northwestern Mediterranean. Marine Ecology Progress Series, 92, 289-300

Font, J., Salat, J. and Tintoré, J. (1988) Permanent features in the circulation of the Catalan sea. Oceanologica Acta, Special Issue, 9, 51-77 
Fraga, F. and Vives, F. (1961) La descomposición de la materia orgánica nitrogenada en el mar. Investigación Pesquera, 19, 65-79

Fraga, F. (1966) Distribution of particulate and dissolved nitrogen in the Western Indian Ocean. Deep-Sea Research, 13, 413-425

Fraga, F. (1969) Distribución del nitrógeno orgánico en el Océano Indico occidental. II. Investigación Pesquera, 33, 163-177

Fraga, F. (1976) Distribución del carbono orgánico particulado en la región de afloramiento del NW de Africa y su relación con el nitrógeno particulado. I marzo 1973. Res. Exp. Cient. B/O Cornide, 5, 19-30

Gasol J.M., M. D. Doval, J. Pinhassi, J. I. Calderón-Paz, N. Guixá-Boixareu, D. Vaqué and C. Pedrós-Alió (1998) Diel variations in bacterial activity and growth in the northwestern Mediterranean Sea. Marine Ecology Progress Series, 164, 107124

Giorgio, P. A., Cole, J. J., Cimbleris, A. (1997) Respiration rates in bacteria exceed phytoplankton production in unproductive aquatic systems. Nature, 385, 148151

Hansell, D. A. (1993) Results and observations from the measurement of DOC and DON in seawater using a high-temperature catalytic oxidation technique. Marine Chemistry, 41, 195-202

Jackson, G. A. and Williams, P. M. (1985) Importance of dissolved organic nitrogen and phosphorus to biological nutrient cycling. Deep-Sea Research, 32, 223-235

Jeffrey, S. W. and Humphrey, G. F. (1975) New spectrophotometric equations for determining chlorophylls a, b, c1 and c2 in higher plants, algae and natural phytoplankton. Biochemical Physiological Planz, 167, 191-194 
Kirchman, D. L. (1993) Dissolved organic material in biogeochemical models of the ocean. In: Towards a model of Ocean Biogeochemical Processes, ed .G. T. Evans and M. J. R. Fasham Serie I: Global Environmental Change Vol.10

Kirchman, D. L., Ducklow, H. W., McCarthy, J. J. and Garsides, C. (1994) Biomass and nitrogen uptake by heterotrophic bacteria during the spring phytoplankton bloom in the North Atlantic Ocean. Deep-Sea-Research I, 41, 879-895

Lefèvre, D., Denis, M., Lambert, C. E., Miquel, J.-C. (1996) Is DOC the main source of organic matter demineralization in the ocean water column?. Journal Marine System, 7, 281-291

Meyers-Schulte, K. J. and Hedges, J. I. (1986) Molecular evidence for a terrestrial component of organic matter dissolved in ocean water. Nature, 321, 61-63

Minas, H. J., Coste, B., Minas, B. (1984). Oceanographie du détroit de Gibraltar et des parages annexes. Le Courr. du CNRS 57: 10-18. Cent. Natl. de Rech. Sci. Paris

Minas, H. J., Minas, M., Coste, B., Gostan, J., Nival, P. and Bonin, M. C. (1988) Production de base et recyclage; une revue de la problematique en Méditerranée nord-occidentale. Oceanologica Acta, Special Issue, 9, 155-162

Norrman, B., Zweifel, U. L. (1995) Production and utilization of dissolved organic carbon during an experimental diatom bloom. Limnology Oceanography, 40, 898-907

Pérez, F. F., Estrada, M. and Salat, J., (1986) Sistema del carbónico, oxígeno y nutrientes en el Mediterráneo Occidental. Investigacion Pesquera, 50, 333-351

Salat, J, (1996) Review of hydrographic environmental factors that may influence anchovy habitats in northwestern Mediterranean. Scientia Marina, 60, Suppl. 2, 21-23 
Salat, J. and Cruzado, A. (1981) Masses d'eau dans la Méditerranée Occidentale: Mer Catalane et eaux adjacentes. Rapp. Comm. Inter. Mer Médit. 27, 201-209

San Feliu, J. M. and Muñoz, F. (1971) Fluctuations d'une années à l'autre dans l'intensité de l'affleurement dans la Mediterranée Occidentale. Investigacion Pesquera, 35, 155-159

Sharp, J. H., Benner, R., Bennett, L., Carlson, C. A., Down, R. and Fitzwater, S. E. (1993a) A re-evaluation of high temperature combustion and chemical oxidation measurements of dissolved organic carbon in seawater. Limnology Oceanography, 39, 1774-1782

Sharp, J. H., Peltzer, E. T., Alperin, M. J., Cauwet, G., Farrington, J. W., Fry, B., Karl, D. M., Martin, J. H., Spitzy, A., Tugrul, S. and Carlson, C. A. (1993b) Procedures subgroup report. Marine Chemistry, 37, 37-50

Sharp, J. H., Benner, R., Bennett, L., Carlson, C. A., Fitzwater, S. E., Peltzer, E. T., Tupas, L. M. (1995) Analyses of dissolved organic carbon in seawater: the JGOFS EqPac methods comparison. Marine Chemistry, 48, 91-108

Sockal R. R., Rolhf, F. .J. (1995) Biometry. Freeman and Company, New York, 887 pp

Strickland, J. D. H. and Parsons, T. H. (1968) A manual of seawater analysis, Fishery Research Board Canada, 167, 310 pp

Taupier-Lepage, I. and Millot, C. (1988) Surface circulation in the Algerian Basin during 1984. Oceanologica Acta, Special Issue 9, 79-86

Thingstad, T. F., Rassoulzadegan, F. (1995) Nutrient limitations, microbial food webs, and 'biological C-pumps’: suggested interactions in a P-limited Mediterranean. Marine Ecology Progress Series, 117, 299-306 
Toggweiler, J. R. (1989) Is the Downward Dissolved Organic Matter (DOM) flux important in carbon transport?. Productivity of the Ocean: Present and Past. eds. W.H Berger. V.S. Smetacek and G.Wefer, pp 65-83

Thomas, C., Cauwet, G. and Minster, J.-M. (1995) Dissolved organic carbon in the equatorial Atlantic Ocean. Marine Chemistry ,49, 155-169

Tupas, L. M., Popp, B. N. and Karl, D. M. (1994) Dissolved organic carbon in oligotrophic waters: experiments on sample preservation, storage and analysis. Marine Chemistry, 45, 207-216

Vaqué, D., Marrasé, C. and Guixa, N. (1994) The trophic dynamics of microbial communities in an oligotrophic sea. ASLO \& PSA 1994 Joint Meeting Florida, USA

Walsh, T. W. (1989) Total dissolved nitrogen in seawater: a new high-temperature combustion method and comparison with photo-oxidation. Marine Chemistry, 26, 295-311

Wangersky, P. J. (1993) Dissolved organic carbon method: a critical review. Marine Chemistry, 41, 61-74

Williams, P. M. and Druffel, E. R. M. (1987) Radiocarbon in dissolved organic material in the central North Pacific Ocean. Nature, 330, 246-248

Williams, P. J. Le B. (1995) Evidence for the seasonal accumulation of carbon-rich dissolved organic material, its scale in comparison with changes in particulate material and the consequential effect on net $\mathrm{C} / \mathrm{N}$ assimilation ratios. Marine Chemistry, 51, 17-29 
Table 1. Selected lineal regressions among the different variables related to organic matter pools: dissolved organic carbon (DOC) or nitrogen (DON), and particulate organic carbon (POC) or nitrogen (PON)). These coefficients were calculated by minimizing the area $\left(y_{i}-y_{i m}\right)\left(x_{i}-x_{i m}\right)$, being $y_{i m}$ and $x_{i m}$ the average values of $y_{i}$ and $x_{i}$, respectively). Numbers in brackets indicate the standard error of the estimated $y$ intercept or slope.

\begin{tabular}{lrrrccc}
\hline Parameters & $\begin{array}{c}\text { Average } \\
\text { ratio }\end{array}$ & SD & $\mathrm{n}$ & Linear relationship & $\mathrm{r}^{2}$ \\
\hline POC vs PON & 8.6 & 0.6 & 63 & $\mathrm{y}=0.37( \pm 0.1)+7.04( \pm 0.2) \mathrm{x}$ & 0.96 \\
DOC vs DON & 15.5 & 0.4 & 47 & $\mathrm{y}=8.1( \pm 3.6)+13.3( \pm 0.8) \mathrm{x}$ & 0.83 \\
DOC vs POC & 20.3 & 2.8 & 63 & $\mathrm{y}=43.9( \pm 2.2)+3.8( \pm 0.3) \mathrm{x}$ & 0.53 \\
DON vs PON & 12.4 & 2.4 & 47 & $\mathrm{y}=2.7( \pm 1.5)+2.2( \pm 0.2) \mathrm{x}$ & 0.49 \\
\hline
\end{tabular}


Table 2. Summary of the DOC values $(\mu M)$ obtained in the present study and comparison with other values reported in Mediterranean waters.

\begin{tabular}{|c|c|c|c|c|c|}
\hline Study area & $\begin{array}{l}\text { Depth } \\
\text { (m) }\end{array}$ & $\begin{array}{l}\text { Average } \pm \\
\text { SD }\end{array}$ & Range & $\mathrm{n}$ & Reference \\
\hline NW Mediterranean & $0-100$ & $68.5 \pm 3.6$ & $52-95$ & 35 & This study \\
\hline Sea- summer & $200-2000$ & $50.9 \pm 1.6$ & $44-63$ & 28 & \\
\hline Western- & $0-2000$ & & $20-70$ & & Banoub and \\
\hline Mediterranean Sea & & & & & Williams 1972 \\
\hline Gulf of Lions & $0-2000$ & & $50-90$ & & Cauwet et al. 1990 \\
\hline “ & $0-2000$ & & $40-200$ & & Cauwet et al. 1997 \\
\hline Ligurian Sea -whole & $0-100$ & & $62.5-100$ & & Copin-Montégut \\
\hline year & $150-2000$ & & $50-60$ & & and Avril 1993 \\
\hline Mediterranean Sea & $0-200$ & & $50-100$ & & Cauwet 1994 \\
\hline
\end{tabular}


Table 3. Summary of the DON values $(\mu M)$ obtained in the present study and comparison with other values reported in Mediterranean waters.

\begin{tabular}{lccccc}
\hline Study area & $\begin{array}{c}\text { Depth } \\
(\mathrm{m})\end{array}$ & $\begin{array}{c}\text { Average } \\
\pm \mathrm{sd}\end{array}$ & Range & $\mathrm{n}$ & Reference \\
& & & & \\
\hline NW Mediterranean & $0-100$ & $4.5 \pm 0.3$ & $3.3-6.2$ & 27 & This study \\
Sea - summer & $150-2000$ & $4.0 \pm 0.2$ & $2.8-4.7$ & 20 & “ \\
Western- & $0-100$ & 5.2 & $3-6.1$ & Banoub and \\
Mediterranean & $100-2000$ & 3.3 & $2.0-4.6$ & Williams, 1972 \\
Alboran Sea & $0-100$ & 4.7 & $3.0-6.3$ & Coste et al. 1988 \\
& $150-800$ & 2.9 & $2.7-3.1$ & “ \\
\hline
\end{tabular}




\section{FIGURE CAPTIONS}

Figure 1. Study area in the Catalan-Balearic Sea. Numbers indicates the position of the stations sampled in the transect studied.

Figure 2. Distribution of A) Salinity, b) Temperature $\left.\left({ }^{\circ} \mathrm{C}\right), \mathrm{C}\right)$ Chlorophyll $a$ concentration ( $\left.\mu \mathrm{g} \mathrm{l}^{-1}\right)$ and D) Oxygen concentration $\left(\mu \mathrm{mol} \mathrm{kg}{ }^{-1}\right)$

Figure 3 Distribution of A) Particulate Organic Carbon (POC, $\mu \mathrm{M}-\mathrm{C}$ ), B) Particulate Organic Nitrogen (PON, $\mu \mathrm{M}-\mathrm{N})$ and $\mathrm{C})$ relation POC:PON

Figure 4. Distribution of A) Dissolved Organic Carbon (DOC, $\mu \mathrm{M}-\mathrm{C}$ ), B) Dissolved Organic Nitrogen (DON, $\mu \mathrm{M}-\mathrm{N})$ and $\mathrm{C})$ relation DOC:DON

Figure 5. Example of the vertical profiles of Dissolved Organic Carbon (DOC, $\mu \mathrm{M}-\mathrm{C}$ ), Dissolved Organic nitrogen (DON, $\mu \mathrm{M}-\mathrm{N}$ ) in the upper $200 \mathrm{~m}$ (top) and down to $2000 \mathrm{~m}$ depth (bottom) at station 7 in the transect studied 


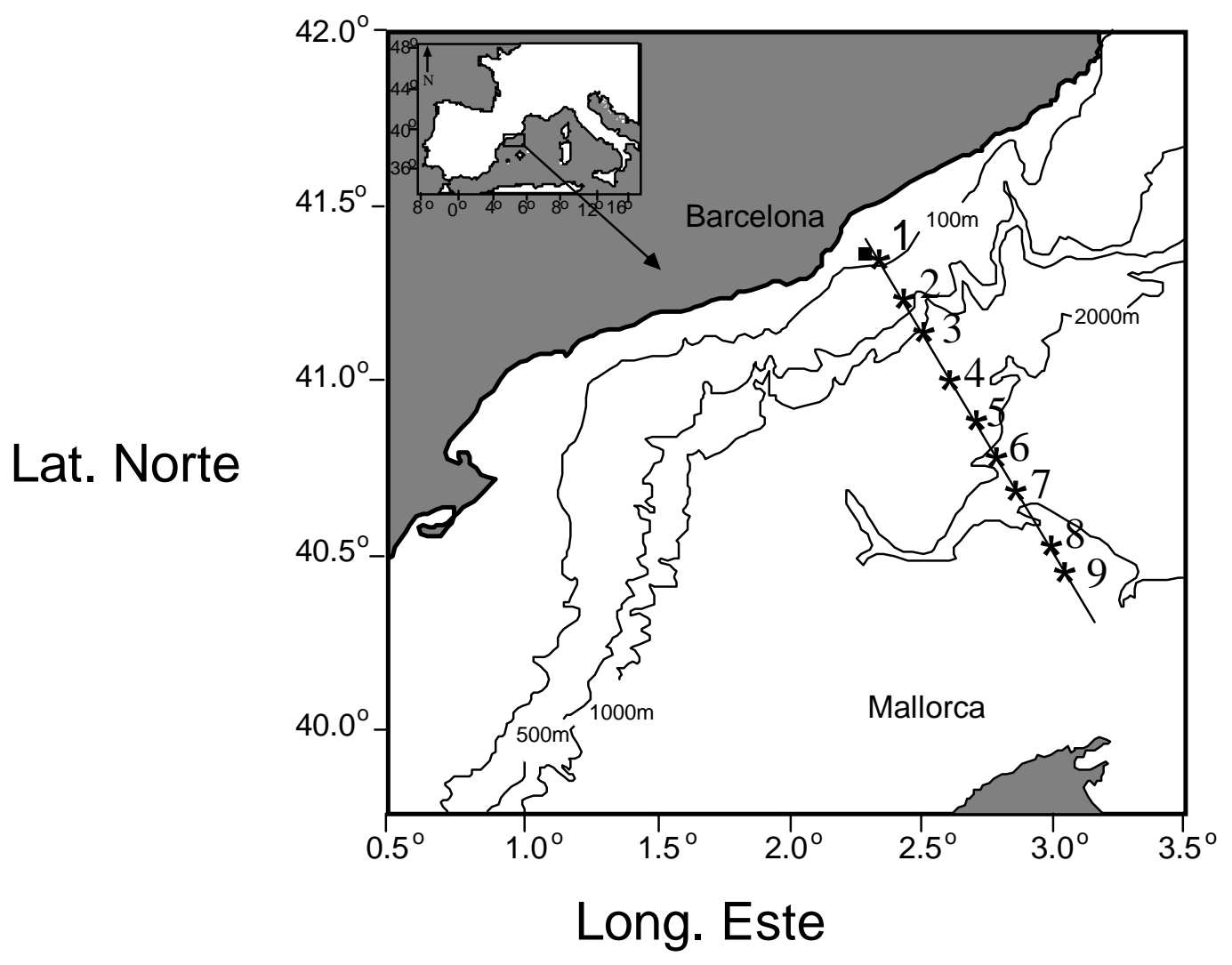

(Fig. 1, Doval et al.,) 

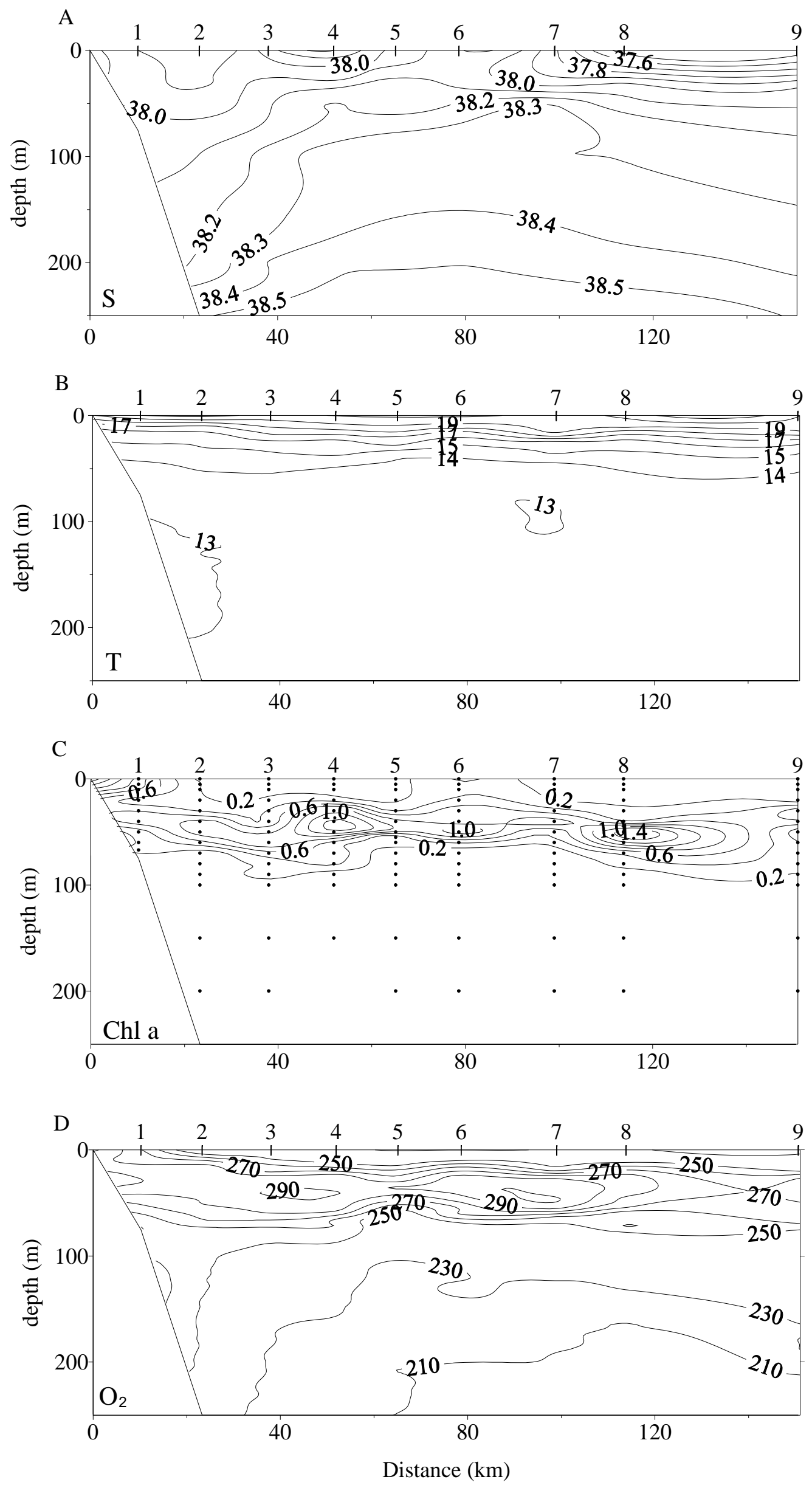

(Fig.2. Doval et al.,) 

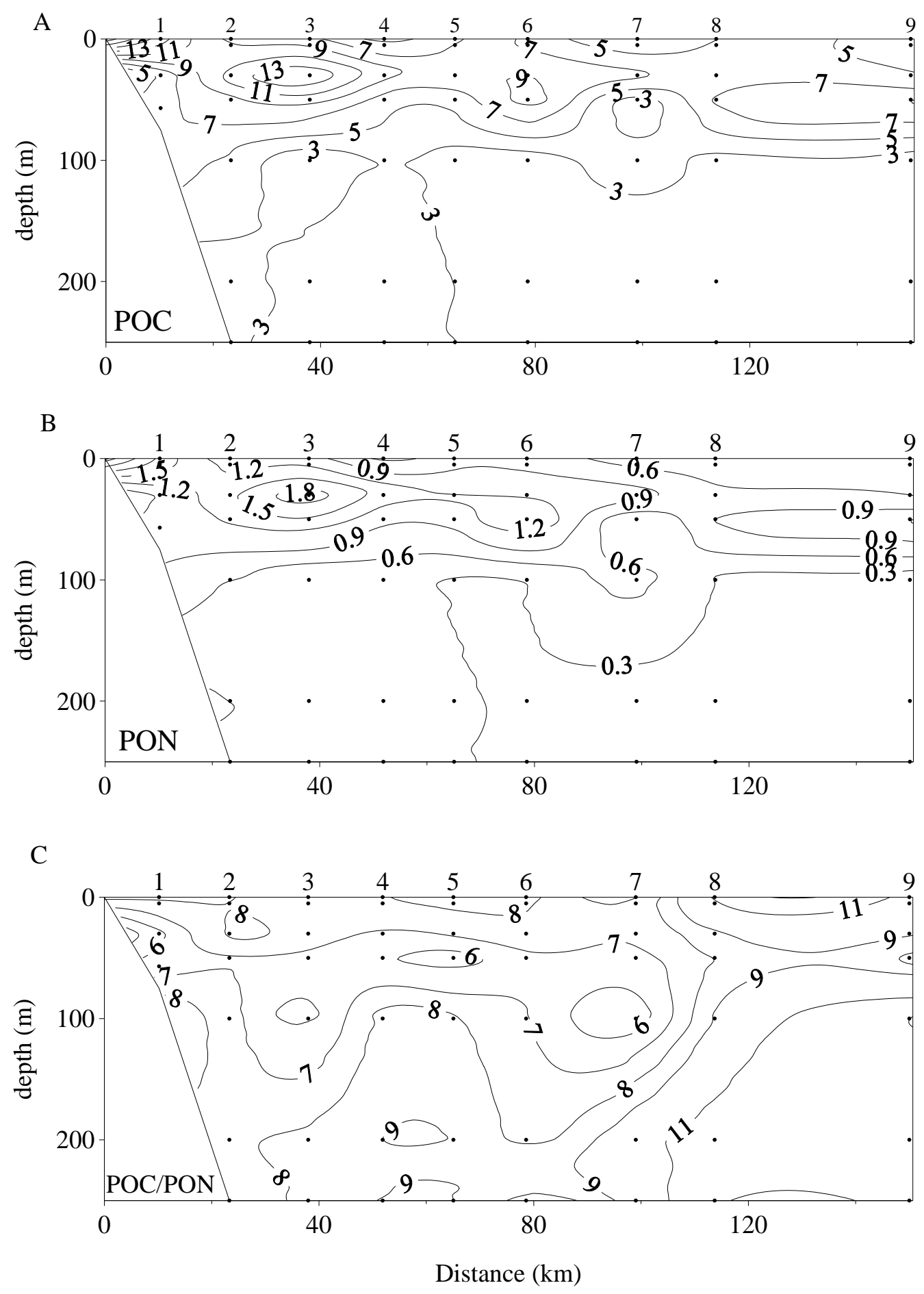

(Fig.3. Doval et al.,) 
A

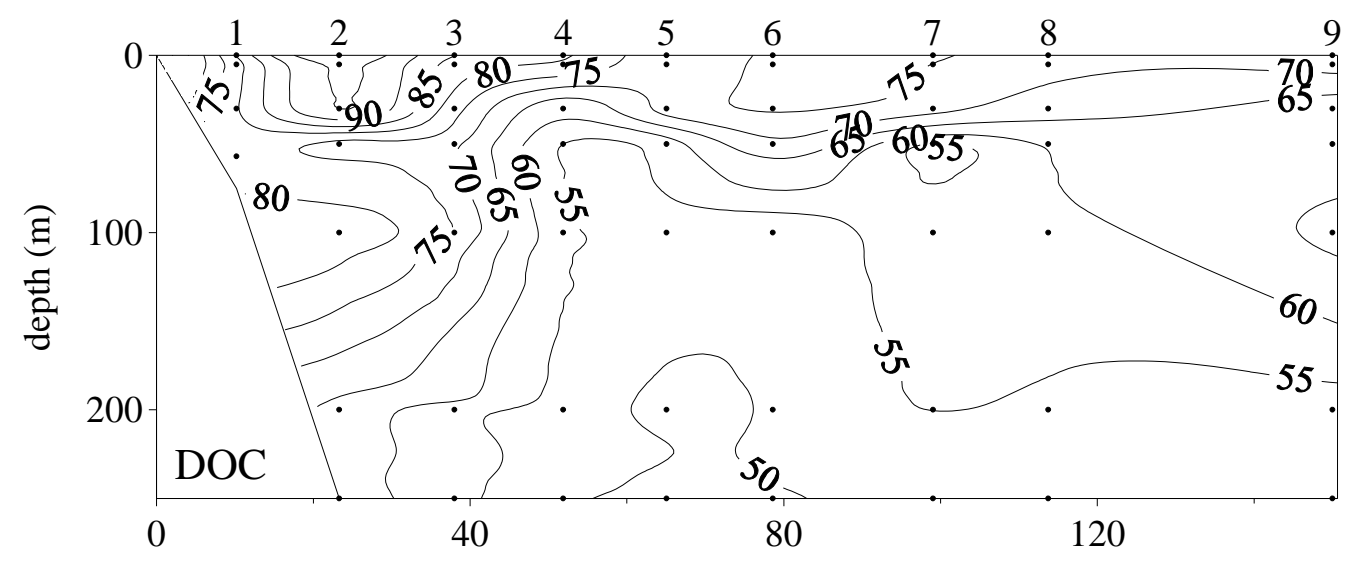

B

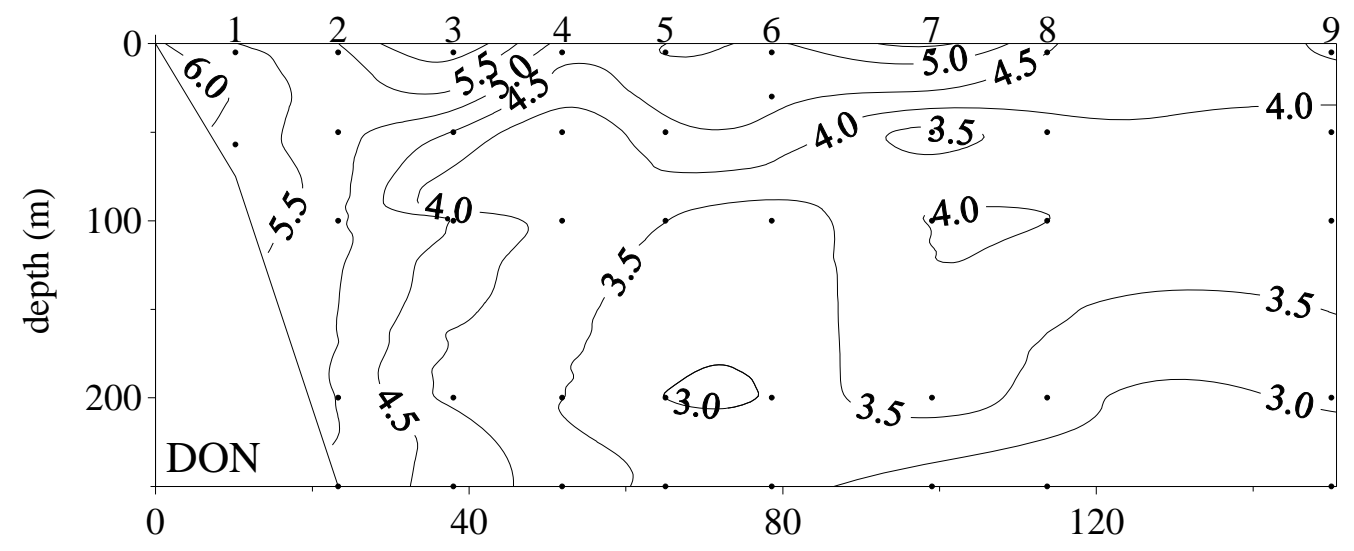

C

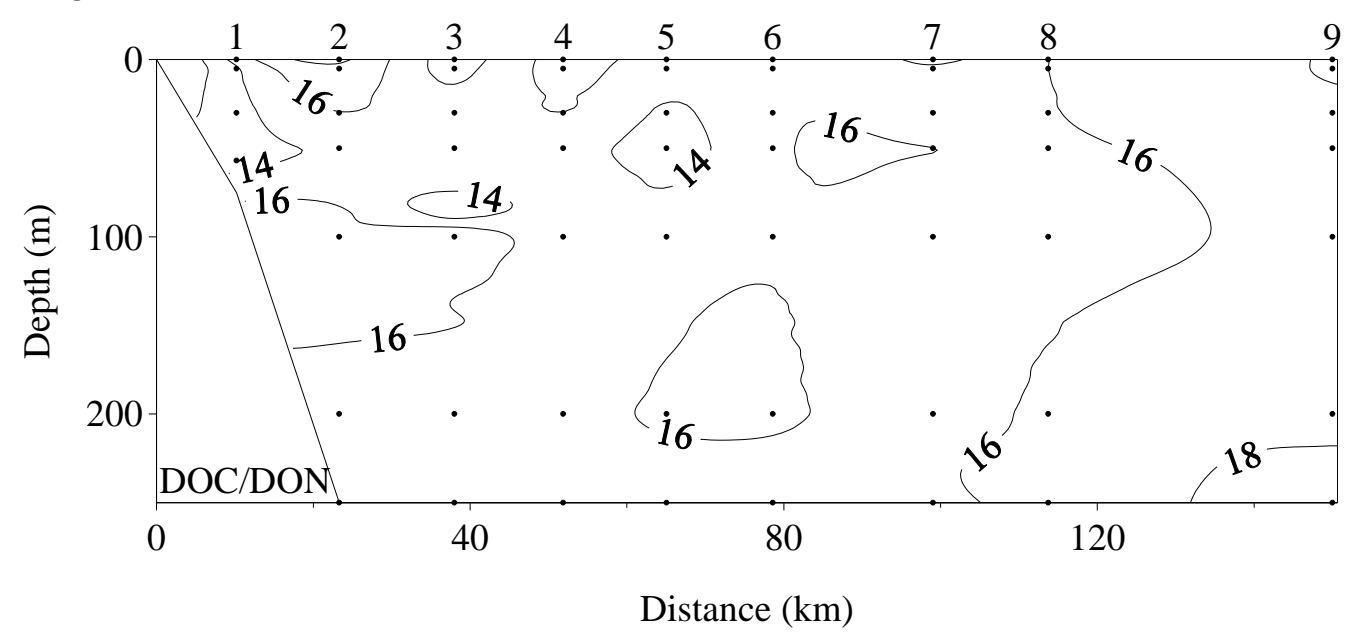

(Fig.4. Doval et al.,) 

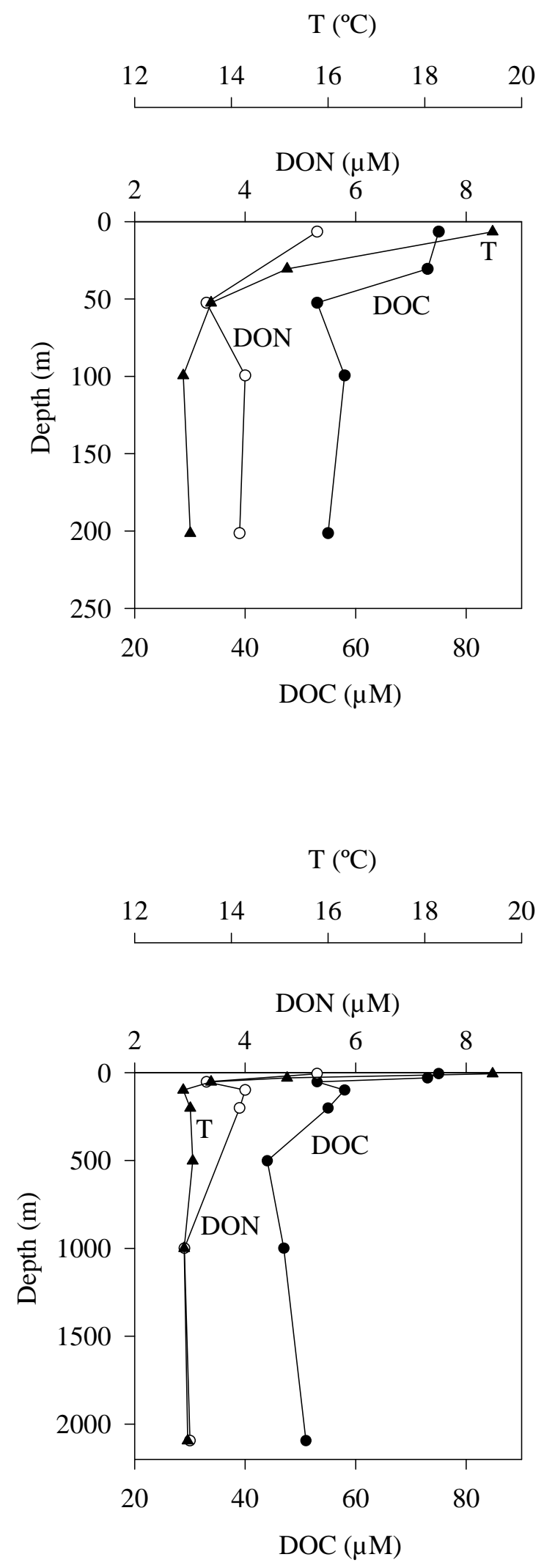

(Fig. 5. Doval et al.,) 